\title{
Standard procedure for the identification of lichen refuges: a case study of the Krajeńskie Lakeland area in Poland
}

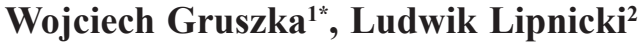 \\ 'Department of Biology, Morphological and Health Sciences, Faculty of Physical Culture in Gorzów Wlkp., \\ Poznan University of Physical Education, Estkowskiego 13, 66-400 Gorzów Wlkp., Poland, \\ "e-mail: elm1@interia.pl \\ ${ }^{2}$ Department of Humanities, The Jacob of Paradies University, \\ Teatralna 25, 66-400 Gorzów Wlkp., Poland
}

Received: 13 August 2019 / Accepted: 8 November 2019

\begin{abstract}
This paper presents guidelines for distinguishing lichen refuges based on research carried out in the Krajeńskie Lakeland region from 2009 to 2014. The main goal of this publication was to establish a methodology to distinguish refuges from other habitats. The main points of this methodology include the precise determination of the research area, comprehensive development of its local lichenobiotic biodiversity, identification of the most valuable species (mainly rare and endangered) and selection of areas with the highest concentration of their stands.
\end{abstract}

Key words: epiphytic lichens, refuge, endangered species, local biodiversity.

\section{Introduction}

The term refugium (from Latin refuge: a place providing safety, protection, shelter) can be used to describe an area or a region where refugees find shelter from areas where their lives are at risk or even threatened with destruction. It follows that a refuge is a place where someone (or something) escapes to in order to find the possibility of safe survival, which is consistent with the definition of Kopaliński (2007). In many languages, the term derived from the Latin word refuge is referred to as a refugee; for example, refugee in English, refugiado in Spanish and réfugié in French. In the natural sciences, a refuge is defined according to Mirek et al. (2005) as a "natural or semi-natural site, distinguished by an exceptional botanical richness and/or constituting a habitat for a distinctive set of rare, endangered and/ or endemic plant species and/or plant communities of high botanical value".
Until now, the problem of refuges and their protection has been treated rather marginally in lichenological literature. This issue is presented as an important research topic in only a few publications (i.e. Cieśliński, 1999, 2000, 2006; Czyżewska et al., 2002; Kossowska, 2002; Kościelniak, 2005, 2009; Wójciak \& Urban, 2012; Kapek, 2014; Gruszka, 2017). Usually, this issue is not subject to detailed analysis, and naming areas refuges is not supported by unambiguous and convincing justification. In many cases, a set of undoubtedly valuable species is given from the studied area; however, due to a lack of proper analysis and interpretation of results, there is a fear that, in some cases, assignment of the rank of refuge may be not justified.

Due to the decreasing number of valuable sites and dying and endangered species of lichens in particular, lichenologists are faced with an urgent need to develop methods to properly distinguish refuges and then postulate to cover these areas with legal protection. Thus, in this 
publication, suggestions and proposals of procedures to help to establish lichen refuges are given, which the authors base on results of their long-term observations and studies on changes in the qualitative and quantitative biodiversity of lichens in selected regions. Also, the authors' experience has been used, especially in the organization of the legal protection of these organisms. This research was carried out mainly in Tuchola Forest and Krajeńskie Lakeland (Lipnicki, 1991, 1993, 2002a, 2006, 2010, 2012; Gruszka, 2009, 2010, 2011, 2012, 2017).

This publication provides an example of the distinction of lichen refuge in the area of Krajeńskie Lakeland, based on the results of an analysis made by Gruszka (2014). It is also extending the issues discussed in the earlier publication of Gruszka (2017) supplemented with the results of further studies on lichen refugia. The presented scheme of conduct should be treated as material for further discussion.

\section{Steps to distinguish a refuge}

The basic standard for distinguishing a refuge within a larger area is the occurrence of valuable, endangered and perishing species; however, it should be kept in mind that the distribution of valuable taxon sites, both on the national scale and in smaller areas (for example in the mesoregion, in the forest complex, etc.), is not a permanent feature. The richness of species is due to the analysed area, diversity of habitats and lichens available to substrates, microclimate, human pressure, including the nature of land use and its changes, and the degree of urbanization. These dependencies are reflected in regional lists of endangered species (i.a. Czarnota, 2003; Czyżewska, 2003a; Lipnicki, 2003; Szczepańska, 2008; Leśniański, 2010; Kościelniak, 2012); these differ not only in a set of taxa, but in the case of the same species, in a different threat status. The distinction of a lichen refuge can be a very important prerequisite for legal protection and/or indication of the way it is managed in its area. Although this task is not troublesome, it is often overlooked by lichenologists.

The determination of a lichen refuge should take place in the following stages:

1) indication of the analysed area boundaries;

2) creation of the list of lichen taxa, including the results of previous (historical) studies, if any;

3) selection of indicator species;

4) creation of a map of the positions all indicator species.

Each of these tasks is usually performed as standard practice during lichenological characterization of an area. An additional analysis of the obtained results will lead to separation of the refuges, which will allow for the submission of the appropriate postulates to the property owners.

\section{Determination of the reference area}

In the initial stages of work, the boundaries of an area on which lichen refuges are expected to exist (e.g. mesoregion, forest complex, city, etc.) should be strictly defined. Failure to do so will not only reduce the value of the work done but may also be the basis for questioning the results.

\section{Determination of indicator species}

To compile a list of lichen taxa whose occurrence will allow for the identification of the refuges within the boundaries of the analysed area, a complete list of species should be created together with the frequency of their occurrence. Among them, select regionally rare, very rare or endangered taxa, including relics of forests (acc. to Cieśliński et al., 1996; Czyżewska \& Cieśliński, 2003b). One should be aware that a list created this way will be unique and characteristic of a given region and cannot be the basis for analysing other areas. If accurate historical results are available, they should also be analysed. As a result, it will be possible to determine the trends and pace of change in lichenobiotic biodiversity; in particular, taxa will be indicated, which deserve special attention due to the drastic reduction in the number of posts.

\section{Stand mapping}

The indicative taxonomic levels should be marked on the maps of the studied area. Concentrations of points will indicate the location of those parts of the terrain in which there are favourable conditions for the survival of the most valuable lichen taxa; they will be refugees.

\section{Case study of the Krajeńskie Lakeland}

\subsection{Determination of the research area}

The mesoregion of the Krajeńskie Lakeland is in northwestern Poland (Fig. 1). It occupies an area of approximately $4380 \mathrm{~km}^{2}$ (Kondracki, 2001). It is located between the Gwda Valley, Brda Valley and Central Noteć Valley, surrounded by Charzykowska Plain and Tuchola Forest in the north. Krajeńskie Lakeland is located between $53^{\circ}$ $05^{\prime}$ and $53^{\circ} 50^{\prime}$ north latitude and between $16^{\circ} 45^{\prime}$ and $17^{\circ} 50^{\prime}$ east longitude (Umiński, 1991). Krajeńskie Lakeland is a typical agricultural land. Forests occupy small areas. A more detailed description of the research area is provided in the article by Gruszka (2017). 


\subsection{Material and methods}

Field studies of the mesoregion were conducted in the years 2009-2014. These studies was conducted with the same methods to the previous ones, aimed to develop a complex characterization of the epiphityc lichenobiotic of the chosen area to determine procedures for identifying the lichen sites (Gruszka, 2017).

Historical data compiled by Tobolewski (1966, 1971, 1979, 1981, 1983, 1988), Tobolewski \& Kupczyk (1977) and Fałtynowicz (1992), as well as unpublished results by Nafalska (1981), Lipnicki (1998, 2001, 2002b) and Winkowska-Grześkowiak (2000) were also analysed. The nomenclature follows the Index Fungorum (date of exploration 01/07/2019).

\section{Results}

In total, 160 species of epiphytic lichens were identified in the Krajeńskie Lakeland as a result of the present research (Gruszka 2014). Of all identified species of lichens, 43 species were identified as indicators of refuges (Table 1); most of them are endangered in the country and they are rare (or very rare) on Krajeńskie Lakeland. Nine areas were marked as lichen refuges (Fig. 2).

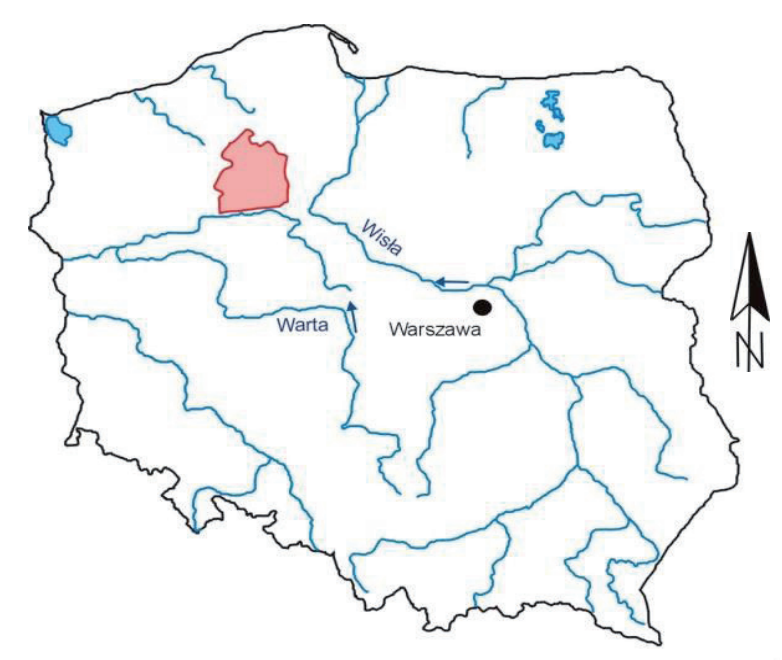

Figure 1. Location of the Krajeńskie Lakeland in Poland
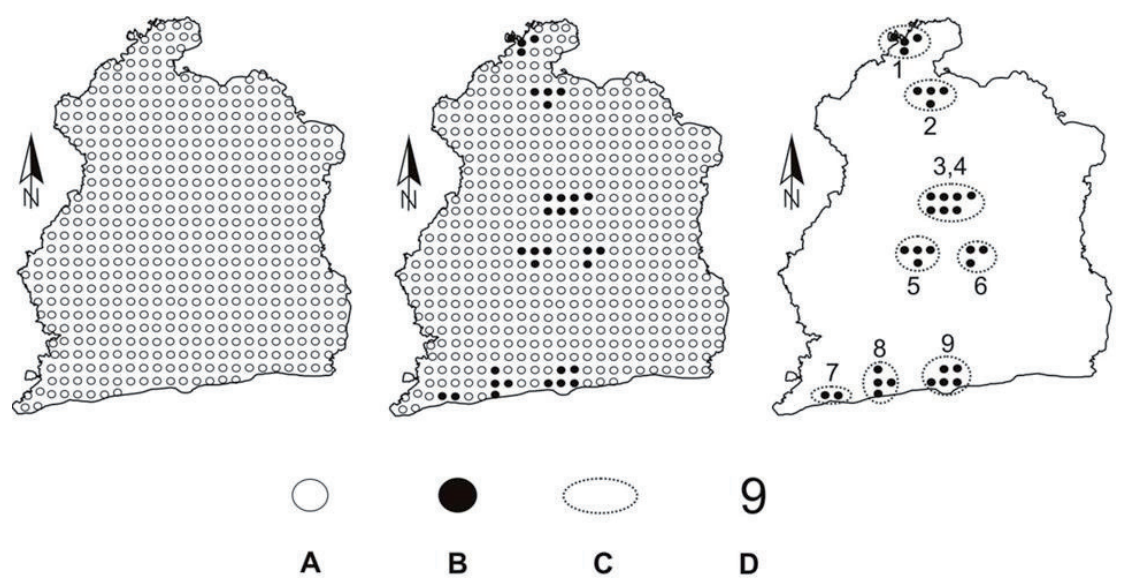

\section{9}

D

Figure 2. The scheme of refuge determination in Krajeńskie Lakeland. A - localities of lichen species, B - localities of selected indicator species, $\mathrm{C}$ - refuge areas; $\mathrm{D}-$ refuges names. Numbering in accordance with the numbering in Table 1 
Table 1. Species that distinguish forest areas as refuges of lichens in the Krajeńskie Lakeland

\begin{tabular}{|c|c|c|c|c|c|c|c|c|c|}
\hline \multirow[b]{3}{*}{ Indicator species } & \multicolumn{9}{|c|}{ Number of refuge } \\
\hline & 1 & 2 & 3 & 4 & 5 & 6 & 7 & 8 & 9 \\
\hline & 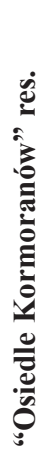 & 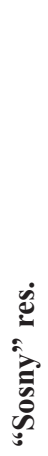 & 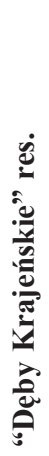 & 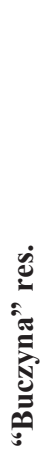 & 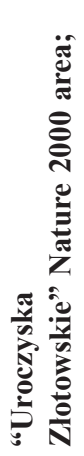 & 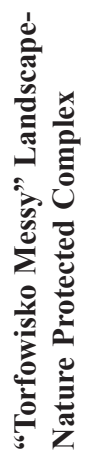 & 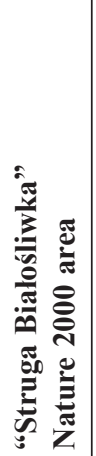 & 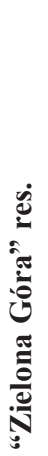 & 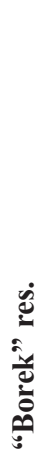 \\
\hline $\begin{array}{l}\text { Acrocordia gemmata } \\
\text { (Ach.) A. Massal. }\end{array}$ & & & & & & & & & * \\
\hline Alyxoria varia (Pers.) Ertz \& Tehler & $*$ & $*$ & & & & * & $*$ & $*$ & \\
\hline Arthonia atra (Pers.) A. Schneid. & & & & $*$ & & & $*$ & & \\
\hline Arthonia spadicea Leight. & & & & $*$ & & & & $*$ & \\
\hline Arthonia vinosa Leight. & & $*$ & & & & & & & \\
\hline $\begin{array}{l}\text { Arthothelium ruanum } \\
\text { (A. Massal.) Körb. }\end{array}$ & & & & $*$ & & & & & \\
\hline Bacidia arceutina (Ach.) Arnold & $*$ & & & & & & & & $*$ \\
\hline $\begin{array}{l}\text { Bacidia circumspecta } \\
\text { (Norrl. \& Nyl.) Malme }\end{array}$ & & & & & & & & & $*$ \\
\hline Bacidia rosella (Pers.) De Not. & $*$ & & $*$ & $*$ & & & & & \\
\hline Bacidia rubella (Hoffm.) A. Massal. & & & $*$ & $*$ & & & & & \\
\hline $\begin{array}{l}\text { Bacidina sulphurella } \\
\text { (Samp.) M. Hauck \& V. Wirth }\end{array}$ & & & $*$ & & & & & $*$ & \\
\hline $\begin{array}{l}\text { Biatora efflorescens } \\
\text { (Hedl.) Räsänen }\end{array}$ & & & & & & & $*$ & $*$ & \\
\hline Biatora globulosa (Flörke) Fr. & & & & & & & & & $*$ \\
\hline $\begin{array}{l}\text { Bryoria implexa } \\
\text { (Hoffm.) Brodo \& D. Hawksw. }\end{array}$ & & $*$ & & & $*$ & & & & \\
\hline Bryoria sophiae (Motyka) Bystrek & & & & & $*$ & & & & \\
\hline $\begin{array}{l}\text { Bryoria vrangiana } \\
\text { (Gyeln.) Brodo \& D. Hawksw. }\end{array}$ & & & & & & $*$ & $*$ & & \\
\hline Calicium adspersum Pers. & & & $* *$ & $*$ & $* *$ & $*$ & $*$ & $*$ & $*$ \\
\hline Calicium salicinum Pers. & & $*$ & $*$ & $*$ & & & & & $*$ \\
\hline Calicium viride Pers. & & & $*$ & & * & & & & $*$ \\
\hline $\begin{array}{l}\text { Chaenotheca brachypoda } \\
\text { (Ach.) Tibell }\end{array}$ & $*$ & & $*$ & & $*$ & $*$ & & & \\
\hline $\begin{array}{l}\text { Chaenotheca brunneola } \\
\text { (Ach.) Müll. Arg. }\end{array}$ & & & $*$ & & & & & & \\
\hline Chaenotheca furfuracea (L.) Tibell & $*$ & & & & $*$ & $*$ & $*$ & & $*$ \\
\hline
\end{tabular}


Table 1 continued

\begin{tabular}{|c|c|c|c|c|c|c|c|c|c|}
\hline \multirow[b]{3}{*}{ Indicator species } & \multicolumn{9}{|c|}{ Number of refuge } \\
\hline & 1 & 2 & 3 & 4 & 5 & 6 & 7 & 8 & 9 \\
\hline & 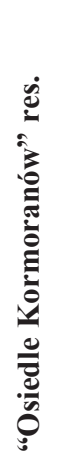 & 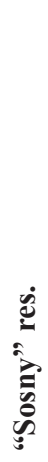 & 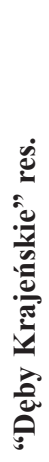 & 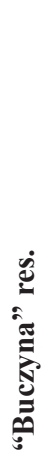 & 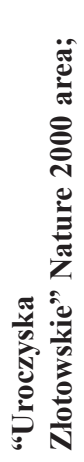 & 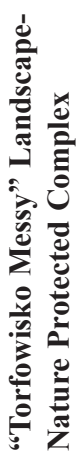 & 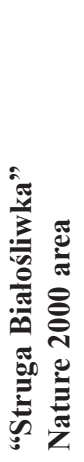 & 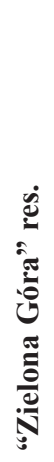 & 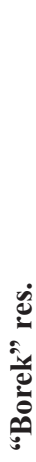 \\
\hline Chaenotheca trichialis (Ach.) Hellb. & & & & & & $*$ & & & \\
\hline $\begin{array}{l}\text { Chrysothrix candelaris } \\
\text { (L.) J.R. Laundon }\end{array}$ & & & $* *$ & $*$ & $* * *$ & * & $*$ & & * \\
\hline Chrysothrix flavovirens Tønsberg & & $*$ & & & & & & & \\
\hline Fellhanera bouteillei (Desm.) Vězda & & & & & $*$ & & & & \\
\hline Gyalecta flotovii Körb. & & & & & * & & & & \\
\hline Hypogymnia farinacea Zopf & & & & & $*$ & & & & \\
\hline Lobaria pulmonaria (L.) Hoffm. & & & & & & & & & $*$ \\
\hline $\begin{array}{l}\text { Micarea elachista } \\
\text { (Körb.) Coppins \& R. Sant. }\end{array}$ & & & $*$ & & $*$ & & & & \\
\hline Micarea melaena (Nyl.) Hedl. & & $*$ & & $*$ & $*$ & & & $*$ & \\
\hline $\begin{array}{l}\text { Opegrapha vermicellifera } \\
\text { (J. Kunze) J.R. Laundon }\end{array}$ & * & & & $* *$ & & & & $*$ & \\
\hline Opegrapha vulgata (Ach.) Ach. & $*$ & $*$ & & & & & & $*$ & \\
\hline $\begin{array}{l}\text { Pertusaria flavida } \\
\text { (DC.) J.R. Laundon }\end{array}$ & $*$ & $*$ & & $*$ & & & & $*$ & \\
\hline Pertusaria leioplaca DC. & $* *$ & $*$ & & $* *$ & $*$ & $*$ & & $* *$ & \\
\hline Pertusaria pertusa (L.) Tuck. & $* *$ & $*$ & & & $*$ & & & $*$ & \\
\hline Pseudoschismatomma rufescens (Pers.) Ertz \& Tehler & & & & $*$ & & * & & & \\
\hline Pyrenula nitida (Weigel) Ach. & $*$ & $*$ & & & $*$ & & $*$ & $*$ & \\
\hline $\begin{array}{l}\text { Pyrenula nitidella } \\
\text { (Flörke ex Schaer.) Müll. Arg. }\end{array}$ & & & & & & & & $*$ & \\
\hline Ramalina baltica Lettau & $*$ & & & & & & & & \\
\hline $\begin{array}{l}\text { Toniniopsis subincompta } \\
\text { (Nyl.) Kistenich, Timdal, Bendiksby \& S. Ekman }\end{array}$ & & & & & $*$ & & & & \\
\hline $\begin{array}{l}\text { Usnea fulvoreagens } \\
\text { (Räsänen) Räsänen }\end{array}$ & & & & & $*$ & & & & \\
\hline $\begin{array}{l}\text { Varicellaria hemisphaerica } \\
\text { (Flörke) I. Schmitt \& Lumbsch }\end{array}$ & * & & $*$ & $*$ & $*$ & & & $*$ & * \\
\hline
\end{tabular}

Descriprions: res - nature reserve; number of localities: * $-1 \leq 5 ; * * 6 \leq 10 ; * * \geq 11$ 


\section{Discussion}

Based on the authors' opinions presented in this paper, patterns of proceedings are based on:

- examination of the whole biota of lichens in a specific area;

- selection of index species (i.e. rare and/or the most endangered), including relics of primeval forests;

- prediction of areas with the highest concentration of positions of distinguished species.

This may look too simplistic, but it allows for the indication of lichen refuges (without resorting to other methods) and it is necessary when considering the importance of obtaining appropriate and non-negotiable results. The procedure itself does not require absolute support from statistical analysis, although this can also be helpful.

The analysis of relatively little historical data did not provide enough information about possible directions of lichenobiotic changes. Based on this, it was also not possible to indicate species which, due to the drastic reduction in the number of positions, would deserve attention. Available data indicate that the few positions are located mainly in the central and northern parts of the Krajeńskie Lakeland.

The eastern and southern regions were less researched, which was probably associated with a greater transformation of these areas and thus with their lower scientific attractiveness. Available historical data contained only a suggestion about lichenologically higher values in the vicinity of Kujania (Nafalska, 1981; Tobolewski, 1979) and the Buczyna Reserve (Lipnicki, 2002b). The studies conducted in 2009-2014 in both areas confirmed the significant lichenological values of these areas. In both areas, refuges were selected: Kujańskie Uroczysko and Buczyna Reserve. This confirms that historical research is valuable for determining refuges only when it has been carried out comprehensively and with due diligence; extracting conclusions based on fragmented data can produce misleading results.

For each species, there is a population threshold below which the population faces a danger of dying out (Wilson, 1999). Based on this axiom, documenting the fulfilment of the function of a refuge in a given area may and should be the basis for legal protection (e.g. reserve, ecological use, natural monument). When proposing forms of protection, ecological requirements of protected species should be considered (Faltynowicz, 1997). The most important and the most effective method is in situ protection (Cieśliński \& Czyżewska, 2002) based on multidirectional actions undertaken for the sake of permanent preservation of all elements of biodiversity associated with their natural occurrence and their natural development processes. In practice, however, such actions are taken sporadically in relation to lichens. The authors realise that the presented theses and propositions do not exhaust the whole problem of lichen refuges. They count on their critical evaluation and verification by the lichenologists' community and they hope for a substantive discussion, because new conclusions may be formulated to complement the discussed topic.

\section{Conclusions}

1. A complete, even a rich list of currently occurring species cannot be the only or the basic criterion for recognizing the area as a refugee.

2. When creating a list of indicator species for the refuge, each area should be considered individually - this will allow protecting the region's most valuable species. Spatial and species variation of lichens are a result of the operation of numerous factors, related to, for example, the size of the area, level of the regional anthropopressure, microclimate and others.

3 . With respect to refuge typing, complete historical data are particularly valuable, allowing for the tracking of the degree and direction of changes in the biota of lichens, selection of the most valuable species or the most endangered species and indication of the existence of areas with the best-preserved biota of lichens.

4. Since the problem of the refuge is not often discussed in the lichenological literature, it is advisable to continue researching this problem in other areas.

5. Research on lichen refuges, although only related to epiphytes, may be applied to other habitat groups.

\section{References}

Cieśliński S., 1999, Ostoja bioróżnorodności flory porostów w uroczysku leśnym „Żyznów” koło Klimontowa [Biodiversity of lichen flora in forest range 'Żyznów' near Klimontów], [in:] T. Puszkar (ed.), Bioróżnorodność obszarów stykowych Kotliny Sandomierskiej, Wyżyny Kielecko-Sandomierskiej oraz Wyżyny Lubelskiej, materiały z sympozjum, Sandomierz 23 września 1999, [Biodiversity of ecotones between Sandomierz Valley, Kielce-Sandomierz Uplands and Lublin Upland, Symposium materials, Sandomierz 23 September 1999], Towarzystwo Naukowe Sandomierskie [Scientific Society of Sandomierz], Sandomierz: 10-22.

Cieśliński S., 2000, Białe Ługi Reserve: a refuge of the forest lichen flora of the Góry Świętokrzyskie Mountains. Fragmenta Floristica et Geobotanica 45(1-2): 485-492. 
Cieśliński S., 2006, The Krzemionki Opatowskie Reserve: a refuge of lichen in Central Poland, Nature Conservation 62: 13-25.

Cieśliński S. \& Czyżewska K., 2002, Porosty Puszczy Białowieskiej na tle innych kompleksów leśnych w Polsce Północno-Wschodniej [Lichens of Białowieża primeval forest in comparison with other forest complexes in north-eastern Poland], Kosmos 51(4): 443-451.

Cieśliński S., Czyżewska K., Faliński J.B., Klama H., Mułenko W. \& Żarnowiec J., 1996, Relikty lasu puszczańskiego. Zjawiska reliktowe [Relicts of the primeval (virgin) forest: relict phenomena], [in:] Białowieski Park Narodowy (1921-1996) w badaniach geobotanicznych [Białowieża National Park in geobotanical research], J.B. Faliński (ed.), Phytocoenosis 4: 47-64.

Czarnota P., 2003, Czerwona lista porostów zagrożonych w Gorcach [Red List of threatened lichens in Gorce Mts.]. Monographiae Botanicae 91: 159-176.

Czyżewska K., Cieśliński S., Motiejūnaitė J. \& Kolanko K., 2002, The Budzisk nature reserve as a biocentre of lichen diversity in the Knyszyńska Large Forest (NE Poland). Acta Mycologica 37 (1/2): 77-92.

Czyżewska K. \& Cieśliński S., 2003a, Czerwona lista porostów zagrożonych w Puszczy Białowieskiej [Red List of threatened lichens in the Białowieża Oldgrowth Forest], [in:] K. Czyżewska (ed.), Zagrożenie porostów w Polsce [Threat to lichens in Poland]. Monographiae Botanicae, 91: 107-120.

Czyżewska K. \& Cieśliński S., 2003, Porosty - wskaźniki niżowych lasów puszczańskich w Polsce [Lichens indicators of lowland old-growth forests in Poland], [in:] K. Czyżewska (ed.), Zagrożenie porostów w Polsce [Threat to lichens in Poland]. Monographiae Botanicae, 91: 223-239.

Fałtynowicz W., 1992, Porosty Pomorza Zachodniego. Studium ekologiczno-geograficzne [The lichens of Western Pomerana (NW Poland). An ecogeographical study]. Polish Bot. Stud. 4: 1-182.

Fałtynowicz W., 1997, Zagrożenia porostów i problemy ich ochrony [Threat to the lichens and problems of lichen conservation]. Przegląd Przyrodniczy. 8(3): 35-46.

Gruszka W., 2009. Porosty rezerwatu przyrody „Kuźnik” ze szczególnym uwzględnieniem gatunków chronionych i zagrożonych w Polsce [Lichens of the Nature Reserve 'Kuźnik' with particular attention of protected and threatened species in Poland], [in:] P. Owsianny (ed.), Rynna Jezior Kuźnickich i rezerwat przyrody „Kuźnik”: bioróżnorodność, funkcjonowanie, ochrona i edukacja [The Kuźnik Lakes Valley and „Kuźnik” Nature Reserve - biodiversity, functioning, nature protection and education]. Wyd. Muzeum Stanisława Staszica, Piła: 72-76.
Gruszka W., 2010, Zmiany bioty porostów rezerwatu „Dębina” koło Wągrowca [Changes of the lichen biota in the „Dębina” nature reserve near Wągrowiec], Badania Fizjograficzne, Ser. B Botanika. 1(59): 173-183.

Gruszka W., 2011, Biota porostów rezerwatu przyrody „Diabli Skok” koło Szwecji (północno-zachodnia Polska) [The lichen flora of the „Diabli Skok” reserve near Szwecja (north-western Poland)]. Chrońmy Przyrodę Ojczystą 67(1): 55-61.

Gruszka W., 2012, The protected and threatened lichens of the roadside trees in the Krajeńskie Lakeland, [in:] L. Lipnicki (ed.), Lichens Protection - Protected Lichen Species, Sonar Literacki, Gorzów Wielkopolski: $277-286$.

Gruszka W., 2014, Refugia porostów epifitycznych na Pojezierzu Krajeńskim [Epiphytic lichens refuge in the Krajeńskie Lakeland], (unpublished doctoral dissertation). Nicolaus Copernicus University, Torun.

Gruszka W., 2017, The concept of lichen refugia classification. A proposal based on the case study of Krajeńskie Lakeland, Poland. Ecological Question 27(3): 65-75.

Index Fungorum, 2019, http://www.indexfungorum.org/ names/names.asp [Accessed 01.07.2019].

Kapek M., 2014, Opuszczone wsie w Bieszczadach jako ostoje zagrożonych i chronionych gatunków porostów w Polsce [Vanished villages in the Bieszczady Mts as refuges of threatened and protected lichens in Poland]. Fragm. Florist. Geobot. Polon. 21(1): 147-164.

Kondracki J., 2002, Geografia regionalna Polski [The regional geography of Poland], Państwowe Wydawnictwo Naukowe, Warszawa.

Kopaliński W., 2007, Słownik wyrazów obcych i zwrotów obcojęzycznych [Dictionary of foreign word and phrases]. Wyd. Rytm, Warszawa.

Kościelniak R., 2005, Ostoja porostów w dolinie potoku Smorż koło Ustrzyk Dolnych [Lichen refuge in the Smorż stream valley near Ustrzyki Dolne], Roczniki Bieszczadzkie 13: 249-259.

Kościelniak R., 2009, The Bieszczady Mts as a Refuge for Protected and Threatened Lichens in Poland, [in:] Z. Mirek, A. Nikel (eds.),Rare, relict and endangered plant species in Poland. Szafer Institute of Botany, Polish Academy of Sciences, Kraków: 269-275.

Kościelniak R., 2012, Red list of threatened lichens in the Bieszczady National Park, [in:] L. Lipnicki (ed.), Lichens Protection - Protected Lichen Species. Sonar Literacki, Gorzów Wielkopolski: 301-311.

Kossowska M., 2002, Ostoja rzadkich porostów epifitycznych na jodłach w Wąwozie Szklarki (Karkonoski Park Narodowy) [Refuge of rare epiphytic lichens on firs in Szklarka Gully (Karkonosze National Park). 
Przyroda Sudetów Zachodnich [Nature of the Western Sudetes] 5: 85-92.

Leśniański G., 2010, The lichen biota of Opole Silesia (South Poland). Part 1. The list of lichen species. Wyd. Uniwersytetu Opolskiego, Studia i Monografie 431: 1-162

Lipnicki L., 1991, Propozycje ochrony stanowiska porostów Ascomycetes lichenisati na terenie Borów Tucholskich [Proposed programme for preserving the lichen stations Ascomycetes $l i$ chenisati in Bory Tucholskie]. Parki Narodowe i Rezerwaty Przyrody [National Parks and Nature Reserves] 10(3-4): 138-150.

Lipnicki L., 1993, Lichenologiczne wartości Borów Tucholskich i ich ochrona [The lichen flora of the Tuchola Forests and its peculiarities]. Chrońmy Przyrodę Ojczystą . 49(5): 43-50.

Lipnicki L., 1998, Inwentaryzacja lichenologiczna ozów krajeńskich [Lichenological inventories of Krajeńskie Lakeland's eskers], (unpublished report). Voivodeship Office, Bydgoszcz.

Lipnicki L., 2001, Lichenologiczna ocena wybranych fragmentów zachodniej części Pojezierza Krajeńskiego [Lichenological valorization of the selected parts of western Krajeńskie Lakeland], (unpublished report). Voivodeship Office, Bydgoszcz.

Lipnicki L., 2002a, Porosty rezerwatu „Dolina Rzeki Brdy" w Tucholskim Parku Krajobrazowym [The lichens in the 'Valley of Brda River' Reserve in the Tucholski Landscape Park], [in:] M. Ławrynowicz, B. Rózga (eds.). Tucholski Park Krajobrazowy 1985 2000. Stan poznania [Tucholski Landscape Park 1985-2000], Uniwersytetu Łódzkiego: 368-384.

Lipnicki L., 2002b, Wyniki inwentaryzacji przyrodniczej rzadkich, najciekawszych taksonów porostów oraz miejsc ich występowania na terenie Krajeńskiego Parku Krajobrazowego [Results of the inventory of rare and most interesting lichen taxons and their locations from Krajna Landscape Park], (unpublished report). Voivodeship Office, Bydgoszcz.

Lipnicki L., 2003, Czerwona lista porostów zagrożonych w Borach Tucholskich [Red List of threatened lichens in the Tucholskie Forest], [in:] K. Czyżewska (ed.), Zagrożenie porostów w Polsce [Threat to lichens in Poland]. Monographiae Botanicae 91: 81-90.

Lipnicki L., 2006, Protected lichens in the Bory Tucholskie Forest (N Poland) and threats to them, [in:] A. Lackovičová, A. Guttova, E. Lisická, \& A. Lizoň (eds.), Central European lichens: diversity and threat. Mycotaxon Ltd., Ithaca: 331-336.

Lipnicki L., 2010, Najcenniejsze porosty Tucholskiego Parku Krajobrazowego i ich ochrona [The most valuable lichens in Tuchola Landscape Park (N Poland) andtheir protection], [in:] A.E. Ławniczak (ed.), Och- rona przyrody w Tucholskim Parku Krajobrazowym [Nature protection in Tuchola Landscape Park]. Wyd. Wyższej Szkoły Zarządzania Środowiskiem, Tuchola: 78-95.

Lipnicki L., 2012, Porosty w Parku Narodowym „Bory Tucholskie" [Lichens of Tuchola Forest National Park], [in:] J.M. Matuszkiewicz (ed.), Świat roślin i grzybów Parku Narodowego „Bory Tucholskie” [Plants and mushrooms of Tuchola Forest National Park] Park Narodowy „Bory Tucholskie”. Charzykowy: 316-357.

Mirek Z., Nikel A., Paul W. \& Wilk Ł. (eds.), 2005, Ostoje roślinne w Polsce [Important Plant Areas in Poland]. Wyd. Inst. Botaniki im. W. Szafera PAN, Kraków.

Nafalska W., 1981, Porosty okolic Złotowa [Lichens in the area of Złotów], (unpublished master's dissertation). Adam Mickiewicz University, Poznań.

Szczepańska K., 2008, Antropogeniczne przemiany bioty porostów Masywu Śnieżnika i Gór Bialskich [Anthropogenic changes of lichen biota of Snieżnik Massif and Bialskie Mountains]. Acta Botanica Silesiaca, Monographiae 4.

Tobolewski Z., 1966, Rodzina Caliciaceae (Lichenes) w Polsce [The family Caliciaceae (Lichenes) in Poland]. Prace Komis. Biol. PTPN 24(5): 1-101.

Tobolewski Z., 1971, Porosty (Lichenes). Atlas rozmieszczenia roślin zarodnikowych w Polsce [Lichens (Lichenes). Atlas of the geographical distribution of spore-plants in Poland], Vol. 1. Series III. Państwowe Wydawnictwo Naukowe, WarszawaPoznań.

Tobolewski Z., 1979, Porosty (Lichenes). Atlas rozmieszczenia roślin zarodnikowych w Polsce [Lichens (Lichenes). Atlas of the geographical distribution of spore-plants in Poland], Vol. 3. Series III. Państwowe Wydawnictwo Naukowe, WarszawaPoznań.

Tobolewski Z., 1981, Porosty (Lichenes). Atlas rozmieszczenia roślin zarodnikowych w Polsce [Lichens (Lichenes). Atlas of the geographical distribution of spore-plants in Poland], Vol. 7. Series III. Państwowe Wydawnictwo Naukowe, WarszawaPoznań.

Tobolewski Z., 1983, Porosty (Lichenes). Atlas rozmieszczenia roślin zarodnikowych w Polsce [Lichens (Lichenes). Atlas of the geographical distribution of spore-plants in Poland], Vol. 8. Series III. Państwowe Wydawnictwo Naukowe, WarszawaPoznań.

Tobolewski Z., 1988, Porosty (Lichenes). Atlas rozmieszczenia roślin zarodnikowych w Polsce [Lichens (Lichenes). Atlas of the geographical distribution of spore-plants in Poland], Vol. 9. Series III. 
Państwowe Wydawnictwo Naukowe, WarszawaPoznań.

Tobolewski Z. \& Kupczyk B., 1977, Porosty (Lichenes). Atlas rozmieszczenia roślin zarodnikowych w Polsce [Lichens (Lichenes). Atlas of the geographical distribution of spore-plants in Poland], Vol. 4. Series III. Państwowe Wydawnictwo Naukowe, WarszawaPoznań.

Umiński J., 1991, Pojezierze Krajeńskie [Krajeńskie Lakeland]. Wyd. PTTK „Kraj”, Warszawa.

Wilson O., 1999, Różnorodność życia [The Diversity of Life], Państwowy Instytut Wydawniczy, Warszawa.
Winkowska-Grześkowiak A., 2000, Flora porostów północnej części Pojezierza Krajeńskiego [The lichen flora of the northern part of Krajeńskie Lakeland], (unpublished master's dissertation). University of Gdańsk, Gdańsk.

Wójciak H. \& Urban D., 2012, Small mid-forest and midfield peatbogs as a refuge of rare and protected lichens species, [in:] L. Lipnicki (ed.), Lichens Protection - Protected Lichen Species. Sonar Literacki, Gorzów Wielkopolski: 133-141. 